\title{
Divine designation in the use of the Bible: The quest for an 'all-powerful God' (the omnipotence of God) in a pastoral ministry of human empowerment
}

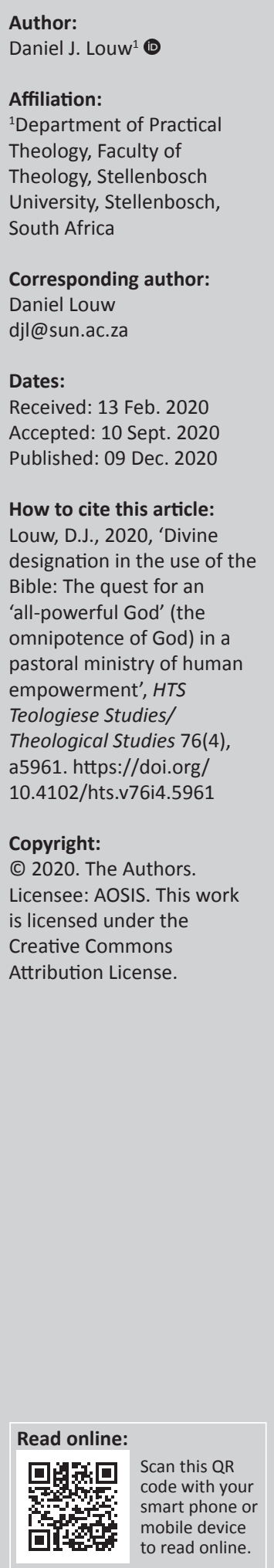

In our exposure to weakness, vulnerability, loss, anguish and different forms of impairment, the following pastoral theological questions arises: What is meant by divine almightiness within the human need for spiritual strength, empowerment, encouragement and well-being? The epithet of almightiness (omnipotence, pantokratōr) gave birth to fictitious and speculative associations, even fear and anxiety: The paralyzing fear of God Almighty - divine intoxicating and spiritual pathology. Instead of a pantokratōr-definition of God, a paraklēsis-infinition of God is proposed. This paradigm shift is based on the hermeneutical insight, namely, that the El Shadday of Yahweh is based on the respect in Jewish hermeneutics to render God not as a personified substance, but as an 'operating verb' - hjh. In the verbing of God, El Shadday points to encouragement, empowerment and a kind of pity and comfort based on the passio Dei.

Contribution: How one perceives the power of God, determines the practice of Christian devotion and spirituality. Therefore, the emphasis on the notion of 'God Almighty' (omnipotence of God) and its link to the notion of the 'weakness of God' as exposed in the basic outline for a theology of the cross and as a source for hope in pastoral care and compassionate reaching out.

Keywords: God Almighty; omnipotence of God; God pantokratōr; hermeneutics of paradoxical parallelism; abuse of the Bible in pastoral theology; all-powerful God; human empowerment.

\section{Introduction and background: The quest for empowerment}

One of the characteristics of pastoral ministry is that caregivers are constantly engaged with the suffering of human beings and their plight for healing, well-being, change and empowerment. Frail and weak people need 'spiritual strength' in order to cope with loss whilst facing physical deterioration and inevitable ageing.

It is within the dialectic between powerlessness (despair and despondency) and the spirituality of strength (to manage life and regain power in order to cope with the existential challenges of daily living) that the quest for empowerment (inner strength) comes into play. The need for 'inner strength' and 'social fortification' has even led to new developments in psychology. Besides the notion of 'positive psychology', a new branch has been established in the past 30 years, namely, fortigenetics.

\section{Fortigenetics: The psychological and existential need for empowerment}

Fortology represents a movement away from pathology to constructive enforcement and encouragement (Louw 2016a:244-245, 605), that is, the need to be empowered so that one can respond in a more constructive way to loss and impairment. In this regard, the research of Strümpfer applies. His research on strength as a psychic category refers to the importance of fortigenesis in adult life (Strümpfer 2006:11-36). Fortigenesis (fortis = strong) is about the personal courage and level of resilience in human beings to cope with difficult forms of loss in order to opt for healing and habitual change. It can be related to the emphasis on human well-being in the professions of medical care, counselling, social work and different models of therapy. The intention is to revive the positive components in human behaviour so that people are enabled and empowered to contribute to healthy lifestyles.

The human quest for empowerment had been emphasised by existential philosophy during the First and Second World Wars. Noteworthy in this regard is the thinking of Paul Tillich in his book

Note: Special Collection entitled The use of the Bible in Theology, sub-edited by Willem Oliver (UNISA) 
The Courage to Be (1965). According to him, '[c]ourage is the self-affirmation of being in spite of non-being' (Tillich 1965:152). For this ontic form of self-affirmation, God is introduced as the ground and foundation of being. Human strength is therefore anchored in both an ontology of courage and a foundational theology of empowerment.

\section{Parrhēsia: The spiritual and religious need for empowerment}

The challenge to cope with severe criticism, failure and inner afflictions regarding one's own identity in ministry and caregiving, is well documented in many of the letters of Paul. In his defence against people in congregations who severely questioned his apostolic authority, Paul reminds his readers that his ministry is framed by his apostolic calling, the pneumatic background of his actions (the charisma of the Spirit) and an inner source of power. In this regard, Paul refers to the notion of parrhēsia.

One can argue and say that the equivalent in Scripture for fortigenesis is parrhēsia [boldness of speech and being] (Louw 2016a:244-245), that is, a courage that is not produced by means of merely human achievements but by divine inspiration and the encouragement of the Spirit (pneumatological dimension in human actions and decisionmaking). It is about a kind of pneumatic capacity that originates from God's indwelling spirit in our life; it is about a quality that comes from God's indwelling presence and engagement with human suffering (Ps 8; 1 Th 2:2). Parrhēsia could thus be called a pneumatic quality as linked to pneumatology. As a theological category, parrhesia is linked to what I would like to call 'inhabitational theology'. Parrhēsia should promote spiritual strength and growth in the praxis of healing and the ministry of salvation because of the experience that one is empowered by God's indwelling Spirit.

\section{Supervincimus: ${ }^{1}$ The quest for an all- empowering God in the overcoming of life's burdens}

The point is inner strength, the capacity to endure and exercise devotional obedience, which points to the direction of what one can call in pastoral theology the spiritual need for an 'all-empowering God'. In order to cope with the ministry of caregiving, 'divine designation' and the notion of God's power (almightiness) become fundamental in order to minister to suffering human beings. It is in this regard that the notion of the overcoming (supervincimus) of suffering and a spirituality of almightiness come into play (theology of the omnipotence $^{2}$ of God) (see Hoffman \& Rosenkrantz 2017). According to Rodríguez (2019:485), this attempt of overcoming by means of an omnipotence paradigm leads to speculation and several intriguing paradoxes - for example,

1.See Calvin's translation and use of 'supervincimus' in the vulgate (superiores evadimus) (Parker 2009:342).

2.Colley (2004:1) refers to the very traditional understanding of God's power. 'God is the only being who possesses omnipotence. In the Oxford English Dictionary, "o only being who possesses omnipotence. "n the Oxford English Dictionary, "omnipotence" is defined as "all-powerfulses," or "almightiness." In other words, when God wants something to be done, it is done. God has all power in heaven and on Earth (Mt 28:18), so unlike the limited power of humans, which is constrained by time, space, and force, God's capabilities are limited only by His own character'. the difficulty to merge unexpected loss, suffering, death and dying by the belief in an all-powerful God who can perform miracles and the goodness of a God of love and his divine providence (see the theodicy problem, Louw 2016a:300-362). Another is the paradox between the so-called perfection of God and the imperfection of creation (see Keller 2007:118). ${ }^{3}$ The core problem in the interpretation of God's power is the challenge to move away from 'coercive determinism' to 'divine intervention' ${ }^{4}$ whilst still maintaining a kind of meaningful divine involvement.

\section{From a philosophy of strength (omipotens) to a theology of empowerment (paraklēsis) ${ }^{5}$}

Philosophy plays a detrimental role in the designation of divine power and takes a multidisciplinary approach in practice, that is, theological thinking. In his research on God's almightiness, Van den Brink (1993:273) attends to the link between the philosophical discourse on theodicy and spiritual quest for an all-powering God. He warns against the method of philosophical abstraction that reduces God's existence to a kind of impersonal, logical principle detached from the relational dynamics of a faith perspective, eventually causing the positivism of insoluble paradoxes. Almightiness is also not an epistemological problem (processes of knowing) in order to detect the potential of God - hence, the rejection of an Aristotelian foundationalism (Van den Brink 1993:298). Rather than putting the emphasis on God's actual dominionship (power-over) in terms of the Greek notion of pantokratōr, the point of departure should be in the direction of the intentionality of God and God's ability (the Latin omnipotentia), that is, God's providential care - acting on behalf of his creation (Van den Brink 1993:300.) Instead of the determinism of causality that leads to the diminishing of human responsibility and freedom (creating the paradox of almightiness), almightiness is not a modality but a dispositional concept pointing to the ability and intention of God (Van den Brink 1993:301). Disposition creates space for the free expression of human responsibility and human freedom; it contributes to the ability to make choices (reële keuzemogelijkheid) (Van den Brink 1993:304). Van den Brink's (1993:272) thinking is an attempt to avoid 'competitionlanguage which plays off God's love against his power'.

It is indeed of paramount importance to reckon with the philosophical discourser on all-empowerment (Hoffman \& Rosenkrantz 2017). However, my approach is much more within a pastoral paradigm, that is, how divine interventions function within texts and their contexts in order to detect the

3.Keller (2007:118) reasons that religious experience does not provide substantial and rational proof for the belief that God is omnipotent. 'I will consider four: the perfection of God, the belief that God is the creator of all things, miracles, and beliefs about what God will do to overcome evil'. God is good, because God always lures every new occasion towards the best possible outcome for itself and its relevant future. Keller's $(1975: 569)$ defence of omnipotence is still in the paradigm of a kind of theistic explanation of theodicy.

4.'Es preferible la intervención divina aceptando la libertad y la enseñanza que un determinismo coercitivo por parte de Él' (Rodríguez 2019:485).

5.'In the LXX parakaleō is chiefly used for the Heb. nāham (especially the niph. and piel), be moved to pity, comfort, usually in the latter sense (cf Ps 119:50)' (Braumann 1975:569). 'Where parakaleo is used for other Heb. equivalents, it also means to encourage, strengthen (Deut 3:28; Job 4:3), lead astray (Deut 23:6), or lead along, guide (Exod 15:13)' (Braumann 1975:570). 
practical, theological meaning of the notion of divine almightiness in pastoral caregiving and its motivational role in human actions and decision-making. This shift towards the human need for spiritual empowerment in caregiving is about the quest for comfort and divine concern and/or consolation (paraklessis). Paraklessis means to be strengthened and encouraged in order to cope with the demands of life. In connection to divine pity, it represents comfort and consolation as modes of spiritual and divine empowerment (Braumann 1975:569-571).

My concern therefore is about human empowerment in caregiving and how to address spiritual pathology, that is, the fear of loss and/or rejection (anguish, dereliction, loneliness, psychic suffocation, hopelessness, and anxiety). A spirituality of empowerment is not in the first place about personal need satisfaction or the selfish claim: 'My God'6 must be strong enough to conquer all the evil forces and to counterfeit the claim of all other deities. ${ }^{7}$ My concern is how to link the human quest for meaning and empowerment in suffering to a God-image that can contribute to comfort and enhance the capacity of the 'human soul' to cope with frailty and vulnerability. How does pastoral care enable believers to link their understanding of divine power to loss and anguish? Hence, the intriguing pastoral theological question, who is 'your God' in the face of life's painful trajectories? What is meant by the phrase 'God Almighty'?

The following quotation is noteworthy:

What actually raises the gods above ordinary mortals is primarily their power; a goddess can be more divine than her peers if she is more powerful. This power, however, was, precarious; concentrated in the name of the god, it could be lost if the secret of the name were divulged. (Traunecker in Van der Toorn 1995:671)

\section{Problem identification: 'My God' - Too strong or too weak?}

In prayers, the need for change and healing are often expressed in suffocating modes of manipulative demands for instant help and healing: 'please heal me, otherwise ...'. The impact of an appeal on God's powerful intervention can indeed be devastating if healing does not materialise in terms of personal expectations and psychic needs. Unanswered prayers can lead to doubt, despair, anger and disappointment. The image of an impassable deity is then projected onto God. God is interpreted as being totally absent, not interested in my personal predicament. It can even lead to 'disbelief',

\footnotetext{
6.The danger of the 'my God" claim is that it is based on the Freudian objection that the omnipotence doctrine is a projection of human wishful thinking. It could also feed the fear of many people in their struggle against the abuse of power, violent oppression that the ascription of supreme power to God is inextricably connected with images of political exploitation and/or oppression and male dominance - patriarchalism.

7.According to Hoffman and Rosenkrantz (2017:1), '[o]mnipotence is maximal power Maximal greatness (or perfection) includes omnipotence. According to traditional Western theism, God is maximally great (or perfect), and therefore is omnipotent. Omnipotence seems puzzling, even paradoxical, to many philosophers. They wonder, for example, whether God can create a spherical cube, or make a stone so massive that he cannot move it'. Hoffman furthermore points out the difference between power and ability. 'Power should be distinguished from ability. Power is ability plus opportunity: a being which has maximal ability but which is prevented by circumstances from exercising those abilities would not be omnipotent. Nothing by circumstances from exercising those abilities would not be omnipotent. Nothing could prevent an omnipotent agent from exercising its
endeavour to do so' (Hoffman \& Rosenkrantz 2017:1-2).
}

'distrust' and severe forms of doubt, anguish, despair and dereliction.

\section{Dereliction within the absence of God: Where is 'my God'?}

The impression of the absence of God can even inflict anger and resistance. Psalm 44:23-26 voices this concern in a very alarming exclamation:

Awake, Lord! Why do you sleep? Rouse yourself! Do not reject us forever. Why do you hide your face and forget our misery and oppression? We are brought down to the dust; our bodies cling to the ground. Rise up and help us; rescue us because of your unfailing love. (Psalm 44:23-26)

Suffocation and anguish feed a sense of dereliction. This experience, because of suffering, human weakness and the fear for death, is even articulated in the dying of Christ. The need for 'spiritual strength', 'empowerment' and 'fortification' is articulated in the cry of Christ. 'About three in the afternoon Jesus cried out in a loud voice, "Eli, Eli, lema sabachthani?" (which means "My God, my God, why have you forsaken me?")' (Mt 27:46, NIV). The anguish of Christ is also emphasised in a very profound way in Hebrew 5:7: '[d]uring the days of Jesus' life on earth, he offered up prayers and petitions with fervent cries and tears to the one who could save him from death' (NIV).

The intriguing theological question surfaces, 'how does the appeal onto an all-powerful God fit into this desperate cry of Christ?' The Hebrew text does not refer to any intervention of 'God the Father' or 'God Almighty'. It just refers to the fact that the Son learned the spiritual lesson of obedience through suffering. There is no mentioning of an All-powerful Father or a demanding appeal to an immediate divine and omnipotent intervention.

When anguish is expressed in a desperate cry for divine help, for healing, for rescue, for intervention and soothing comfort, when the plea is accompanied by the belief that 'God is great' and 'strong enough' to intervene in a miraculous way, the following theological questions emerge: 'what kind of Godimage should be introduced to desperate sufferers in the ministry of healing, helping and comfort?' Could the appeal to an all-mighty and omni-potent Godhead not eventually lead to the danger of spiritual pathology - doubt in God's presencing $^{8}$ involvement, disappointment regarding the providential will of God and, eventually, a total disbelief and rejection of the Christian tradition of 'amazing grace'? When prayers become unanswered and you are robbed of all your material, social and psychic certainties, the notion of 'God Almighty' becomes questionable.

8.'Presencing' is a combination between 'presence' and a 'sensual experience' within daily events. It further indicates a kind of encounter wherein the past, present and future intersect in such a way that sensing (experience) and present moment (state future intersect in such a way that sensing (experience) and present moment (state 'of being) coincide in order to create a sense of meaningfulness and purposefulness. 'Presencing' is a blended word combining human experiences and senses (the dimension of the affective) and the realm of being-there (Dasein) (presence as the state of being in the present moment) (Kempen 2015:140). In theologica terminology, it refers to the divine promise to Moses that god will be there where he (Moses) will be operating in the palace of Pharao (Ex 3:14), that is, the act of 'divine presencing' - God coram Deo. 


\section{The power of God: Is 'my God' strong enough?}

In afflictions, doubt arises and the painful question drives one into spiritual craziness: is 'my God' not 'too small' for helping me out of this huge misery? Perhaps, it could be that 'my God' is too weak to overcome the heavy burden of my personal temptation (Martin Luther: Anfechtung) and spiritual depletion?

And with these questions, we are immediately wrestling with the existential predicament of theodicy:

\begin{abstract}
Inbody (1997:140) captures this problem very aptly when he argues that, in our attempt to rethink the meaning of divine power, two things can happen. Our God-image can become 'too small', or 'too big'. If God can only empathize with the suffering of the world, but can do nothing about it, God is too small. If God is identified with nature and can do nothing more than what positivists mean by natural law, God is too small. If God is identified with human capacities, abilities, creativity or human ideals, then God is minimalized. On the other hand, if God is identified with omnipotent power, as the kind of power that, because of definition, can do 'just anything', God is too big. When a theistic notion of divine omnipotence portrays God's kingdom in terms of an empire, He becomes too militant and strong. God is then merely a Hellenistic 'pantokratōr'. (Louw 2000:12-13)
\end{abstract}

In medieval times, the quest for a strong God was summarised by the following tricky formulation: can God make a rock which is too heavy for him to lift and carry away?

Within the parameters of the so-called theodicy problematic, we are challenged to deal with one of the most basic theological questions in a pastoral hermeneutics of caregiving: how does one interpret God's divine intervention and power when faced with total loss, the despondency of personal failure and the reality of illness, ageing, death and dying? The answer to this question inevitably requires a thorough exegesis when biblical texts were used to empower suffocating human beings. Empowerment then in the sense of encouragement and hope by means of the pneumatological perspective: the spiritual fruit of the Spirit as founded by the redemptive work of Christ (theologia crucis) and the vision of the resurrection (theologia resurrectionis). The use, and even abuse of the Bible, is therefore intrinsically a hermeneutical problem within the perspective of God's sacrificial intervention on behalf of suffering human beings.

\section{The abuse of the Bible in theological hermeneutics: The 'repressive mechanism' of manipulating an 'imperialistic God' - 'Strong people' need 'strong Gods'}

Divine designation in biblical reflection and the praxis of pastoral caregiving is one of the most critical challenges in hermeneutics and exegesis. This is specifically the case when the Old Testament must be translated into Greek and other languages. Parker (2009:256) warns as follows: '[o]bscurities in the Hebrew Bible are often resolved in Christian translations by recourse to the Septuagint (which in its extant representatives is unlikely to be free from Christian interpretation)'. He therefore very aptly points out why the use of the Bible in theology is indeed precarious. According to Parker (2009:256), one must be critically aware of the danger of 'intellectual neo-imperialism' in the use of biblical texts. He points out the value of 'textual criticism' as the foundation of studying the Bible.

This very timely warning is critical when concepts like El Shadday and Sabaoth are translated into other languages. The further problem is that one has to reckon with different readings as well. For example, existent is a Hebrew reading, a Jewish orthodox reading, a Greek LXX reading, a Christian reading and an ecclesial reading because of the impact of doctrine and church confessions on the interpretation of biblical concepts such as El Shadday - hence, the questioning of the validity of a translation into omnipotence.

To my mind, the problem of an 'omnipotent God' was captured in a very apt way by the systematic theologian Douglas Hall. He posed the following very challenging question: is the church willing to abdicate from imperialistic interpretations which tried to 'colonise' God's kingdom for our own cultural purposes? Is pastoral care prepared to refuse to be chaplain to the imperium (Hall 1993:135)?

In order to move away from an imperialistic hermeneutics and omni-categories in pastoral caregiving, and to reframe 'divine designation' in terms of what I would like to call the passio Dei, practical and pastoral theology should face the difficult task of reassessing long-standing traditional God-images as fixed by confessional and denominational doctrine; by ecclesial orthodoxy, that is, the quest for a right and correct understanding of the Godhead in terms of prescribed synodal formulations (ecclesial dogma). Especially those God-images that have been emotionally abused to manipulate the will of God, to become subjected to our human need to gain power over the powerless other (the exploitation and oppression of the other) and to create a perfect world free of weakness, pain and suffering should be reassessed.

The point is that powerful people and affluent societies need powerful 'gods' in order to manage life and to control every aspect of our being human (Hall 1993:134-135). For example, in the current coronavirus disease 2019 (COVID-19) discourse, the notion of 'saving human lives' is most of times subordinated to materialistic and economic needs, that is, how to get the economy going, how to control the virus and how the crisis of unemployment can be addressed. Although the importance of producing a vaccine is quite understandable, the appeal is on control and management whilst it becomes difficult to reach out to those who have to struggle with their pain in isolation and a lockdown setting. 


\section{Trumpism: The political need for a kind of spiritual dominion - Camouflaging the truth by colonising God}

The quest for power and the attempt to connect political campaigns to religious paradigms and divine providence is detectable in political circles and election speeches. The critical debate on the impeachment of the president of the United States of America, Donald Trump, refers to the real threat to use religious language in order to gain political power whilst dealing with the problem of the influx of illegal immigrants. The reality of xenophobia instigates attempts to recolonise an all-powerful God in order to make America great again. As Hall (1993:135) aptly remarks: '[s]trong people need strong Gods' (see also Suurmond 1984:42).

In his book, The faith of Donald Trump: A Christian President, Robinson (2017:1) refers to the interplay between Trump's aspirations to become president and his Christian faith. Robinson discusses how Trump's religious beliefs mould his personal life and inform his vision and politics:

His victory, a political miracle greater than any other in recent history, Donald J. Trump's presidency aims to be populous, yet biblically based. He has often said that 'I am a tremendous believer' and 'Christianity helped drive the destiny of my victory'. (see Robinson 2017:1)

In an article with the title 'Jesus, Jacob Zuma, and the New Jerusalem: Religion in the Public Realm between Polokwane and the Presidency', West (2010:43-70) refers to the problem of the repressive mechanism of abusing the Christian faith in order to gain political power. In Pentecostal circles, the comparison between Jesus' mission and Zuma's presidency turned up several times in the media. Van Wyk (2019) refers to this problem:

While Zuma has avoided any convictions, his detractors have been outraged at his lack of shame. He's also been defiant in the face of various criminal charges. Instead of shame, Zuma has often boasted of God's divine support when matters went his way and complained of dark plots when they did not. (Van Wyk 2019:1)

The point is that, in the face of defeat, religion should cover up for personal weakness:

Zuma's religious utterances presented a conundrum for scholars. That's because many poor South African Christians supported his moral claims and celebrated his defiance. Outside the courts where Zuma faced criminal charges, supporters often likened him to Jesus, decried his 'crucifixion' and convened prayer vigils. (Van Wyk 2019:1)

\section{Theism and Christian imperialism (Emperor Mystique)}

It is imperative that research on the designation of Godimages, determining the character of divine intervention, should probe into the realm of iconography and Christian art (Louw 2014, 2020:298-320). In the designation of divine power, the link between Christianity and early depictions of Christ is called the impact of the 'Emperor Mystique' on interpretation of divine power. The 'Emperor Mystique' approach refers to a theory in iconography accepted by art historians, namely that the images of Christ Pantokratōr in early Christian imagery were derived from images of the Roman emperor (Louw 2014:129-133):

Both the shape and the power of the images, according to this theory, come from reliance on imagery formerly used to present the emperor. I call this approach the 'Emperor Mystique'. It is a 'mystique' in so far as it involves a reverence bordering on cult for everything belonging to the emperor. To such historians dropping the word 'imperial' into a discussion represents an appeal to a kind of ultimate value beyond which one never look. (Mathews 1993:12)

It is the conviction of Hall (1993:133) that one of the most repressing God-images of Christian theism and cultural Christian imperialism was 'the Father Almighty' (Louw 2016a). He argues that this very powerful image was misused in the North American continent to insulate people from the reality of their situation. Such a theology, he argues, constitutes part of the:

$[R]$ epressive mechanisms of a class that can still camouflage the truth because it is well-padded economically and physically; and that this theology, accordingly, is partly responsible for the oppression of others who suffer from First World luxury, aggressiveness, and self-deceit. (See Hall 1993:133)

Hall (1993:133-134) calls such a theology that maintains the image of a very imperialistic and even consumerist deity, based on a power principle that can only comfort the comfortable, 'a flagrantly disobedient theology'. God's involvement should be more than mere comfort. Indeed, God comforts the afflicted, but also afflicts the comfortable.

\section{Spiritual pathology and the intoxication of an omni-potent God}

Omni-categories can indeed lead to a kind of spiritual pathology, namely, a fear to approach God - a kind of paralysing fear that suppresses spiritual spontaneity and intimate fellowship. This kind of spiritual pathology can even penetrate the notion of koinonia in such a way that worship becomes formalised and stereotyped in order to satisfy God and to keep a punishing God at bay (Nouwen 1994):

\footnotetext{
God's love for me was limited by my fear of God's power, and it seemed wise to keep a careful distance even though the desire for closeness was immense. I know that I share this experience with countless others. I have seen how the fear of becoming subject to God's revenge and punishment has paralyzed the mental and emotional lives of many people independently of their age, religion, or life-style. This paralyzing fear of God is one of the great human tragedies. (p. 121)
}

The psychoanalyst Tilman Moser (cited in Bachmann 2002:41) calls this 'paralyzing fear of God' a kind of divine intoxication (Gottesvergiftung), that is, a kind of inhumane suffering because of fear for God the Almighty (Leiden an der Allmacht Gottes). The only way then to escape this fear is to diminish oneself to a childlike state with the confession: please God, 
have pity on me, I am only a poor sinner! (Moser in Bachmann 2002:42-43).

But is the pity of God merely applicable to the desperate condition of poor sinners? What about the vulnerability of exploited, poor people?

\section{The case of Deuteronomy 10:17-19: The hermeneutical dilemma and the risk of abusing the Bible in caregiving}

As said, the use of the Bible in theology is a hermeneutical and exegetical problem. It boils down to cultural contexts, existing paradigms, the use of language to express meaning and basic religious presuppositions (dogmatic and doctrinal formula; ecclesial prescriptions) that dictate the mind of translators and readers. Taking all these interpretational filters in mind, one must admit and say that the use of the Bible in theology is a painful risk and always open to abuse and human manipulation. The abuse of the Bible is therefore an inevitable and unavoidable theological risk because of the fact that the use of the Bible can even be called the courageous leap into 'religious gambling' with 'my God' and all-powerful God-images (the annexation of God for personal, selfish gain). We even take the risk of 'smuggling' with 'my God' when making categorical and final statements about God's providence, his will and eventual intentions. One of these very precarious claims is 'my God is so great and strong and will provide in all my needs'; 'my God' is all-powerful and, thus, all-mighty.

The complexity of designating God's almighty power (all-empowerment; omni-potence) is addressed in a very profound way in Deuteronomy 10:17-19. Very surprisingly, immediately after the appeal to 'God Almighty' (God Sabaoth), God's vulnerable, caring compassion and pity is also addressed and revealed in these texts. A general, but serious, reading will immediately pick up a possible logical clash between all-powerful omnipotence and caring compassion. We call this logical clash an apparent fatal hermeneutical paradox.

\section{The apparent fatal paradoxical clash between a 'Warrior God' and a 'Compassionate God'}

When one reads the chapter merely in terms of the two different scenarios, namely, 'God as the remote and immutable warrior', quite distinct from our human misery, and 'God as the intervening and compassionate Carer Comforter' engaged in human misery, one is faced with the hermeneutic of paradox. It seems that the first part and the second part in the Deuteronomy text are so juxtaposed that, apparently, they are opposing one another. It seems as if the text introduces two quite different deities.

Furthermore, if these texts are not read together within the framework of the book and the context of the chapter, it could happen that two different deities emerge in the interpretation. This is the reason why Dreyer warns against the widening of the gap between the image of the biblical God, who sympathises with his children and experiences a wide range of emotions, and the impact of allegorical interpretations, different anthropomorphisms and mythological stories leading eventually to an increasingly dispassionate Greek conception of God as in the case of a pantokratōr image (Dreyer in Van der Horst 1995:697). The latter leads to the intriguing question of God's apatheia. 'The biblical God is a God who acts and speaks, whereas the Platonic god neither acts nor speaks' (Verdenius cited in Van der Horst 1995:696). It becomes clear why hermeneutical attempts to reconcile the diverging images, and to bridge the gap by a bold synthesis of biblical and Greek theology, that eventually had detrimental consequences on Christian theology and reflection on the power of God, can lead to speculative interpretations and skewed perceptions regarding God's empowering interventions with human misery.

When we analyse the two main sections in Deuteronomy 10:17-19, we come across two possible main contrasting designations of divine presence and involvement:

- Mighty and awesome.

'17 For the Lord your God is God of gods and Lord of lords, the great God, mighty and awesome, who shows no partiality and accepts no bribes'.

Verse 17 makes use of warrior terminology. Here, the LXX translates God within the framework of the notion of sěb 'âôt interpreted as pantokratōr. Yahweh zebaoth (sěb'āôt) is a feminine plural of $s \bar{a} b \bar{a}^{\prime}$ (= armies) (Feldmeier 1995:35). In many English Bible translations, zabaoth or zebaoth (the transcriptions vary) refers to 'host of heaven', that is, the council of the gods.

The name Yahweh Zabaoth points to a deity who created the heavenly armies.

- Caring and compassionate.

Verses 18-19 refer to the Exodus tradition:

He defends the cause of the fatherless and the widow, and loves the foreigner residing among you, giving them food and clothing. And you are to love those who are foreigners, for you yourselves were foreigners in Egypt. (Deuteronomy 10:18-19)

Here God is with Israel on their way to the promised land. The Exodus God is the liberating and caring God. He sojourns with his people through a promise expressed in terms of a verb (infinitive tense): I am who I am, and I will always be there where you are (Ex 3:14). God is Sojourner, a Traveller, wandering with his people within the midst of misery, famine, hunger, thirst and death.

The connection between God and Yahweh is indeed of great importance in Hebrew thinking. It is indeed difficult to align 
this verbing of Yahweh with a kind of immutable, subjective abstraction (the metaphysical paradigm). It indicates both a dynamic presence and a vivid promise (I will certainly be there) with future, eschatological implications. In the 'I am' is captured also an allusion to the incomparability of Yahweh (I am who I am; i.e. without peer) (Van der Toorn 1995:1718). Even in the revelation of a name or any other form of designation, Yahweh does not surrender himself; the Godhead cannot be captured by means of either an image or a name or any other depiction. Even attempts to link Yahweh with the concept EL are open to speculation. However, an aspect of Yahweh that may be traced back to El is the notion of God's splendour (hôd) and possibly his 'shine' (těhillâ) as accompanied brightness and rays of light.

Based on the HWY-paradigm (the infinitive of 'to be'), divine intervention and empowerment are opened to the surprising unpredictability of many appearances as God journeys with his people. The hermeneutical dilemma in Deuteronomy 10:17-19 is, how do we interpret this possible paradox between the sovereignty and dominionship of God (Sabaoth) (God is self-sufficient and not dependent on human beings or any other existing deity) and his deep concern for the suffering of people because of injustice, oppression and the abuse of imperialistic power?

An intriguing question further arises: is in this dilemma the translation of God's power into pantokratōr images indeed appropriate and perhaps not a flagrant abuse of the Bible in a pastoral reflection on the presence of God in vital life events?

\section{The pantokratōr image: A misleading interpretation?}

In general, pantokratōr refers to 'almighty', 'all-sovereign' or 'controlling all things', pointing to a divine execution of special designated power. Feldmeier (1995:35), in his research on the meaning of pantokrator , found that relatively rarely in pagan literature it was used for the designation of a deity. However, it was used frequently for God in the LXX and early Jewish writings. His assertion is that pantokratō $r$ was used as an indication of God's power because of a Jewish reaction to the idea of a comprehensive, allencompassing, global power, introduced by Alexander the Great and adopted by the Hellenistic monarchies, and, finally, by the Roman Empire. This emphasis on an imperialistic understanding of divine power was eventually given a religious basis to express the Hellenistic and Roman sense of mission and superiority. In this regard, the translation of divine power into pantokratōr is the result of the continued political and increasing economic dependence of Palestine, and also of the greater pressure on Jewish belief and on the way of life it conditioned in Israel and the diaspora. It is also an indication of the fact how political, economic and cultural contexts determine hermeneutics and the understanding of the biblical narratives in history. Over a longer period of time, the translation gains the status of divine sanctity.
Three kinds of paradigms played a role in the establishment of pantokratōr as representing the all-powerful position and authority of a deity:

1. The connection with monarchic powers of rulership: God is viewed as king (basileus). He reigns with superpowers over a specific dominion. As a result of royal dominionship, God as king will always come to the aid of his citizens. Early Jewish apocryphal and pseudoepigraphical literature seems to confirm this interpretation (Feldmeier 1995:36-37). For example, the all-sovereignty of God in antiquity, as paraphrased by the Persian Great King Darius, played a significant role in the establishment of pantokratōr as designation of divine authority:

Finally, the divine designation pantokratōr must presumably be understood as a Hellenistic-Jewish equivalent to the concept of the Kingdom of God (basileia tou theou), also very important in the preaching of Jesus. (Feldmeier 1995:38)

However, for most of early Christianity, the divine name pantokratōr does not seem to have been of major importance. In the writings of John and the Book of Revelation, the divine attribute of pantokratōr should also be viewed against the background of the political resistance of the Roman Empire. The claim of the early Christian community that the risen Christ is Lord brought about violent persecution. As a result of Roman imperialism and the pax Romano, nobody else could claim any kind of dominionship in the empire. The translation of pantokratōr was an attempt to respond to attempts to exterminate Christians. The term then gained messianic and apocalyptic undertones in order to defend the church against prosecution by Caesar.

2. The connection between God as creator of heaven and earth and his providence: With the pantokrator image, God's lordship over the whole of the cosmos should be expanded. 'The divine attribute pantokratōr therefore stresses, in opposition to the Roman Empire's claim for world power, God's royal power, which embraces the whole cosmos' (Feldmeier 1995:40). This kind of all-embracing rulership and reign (supremacy) implies that an all-powerful God should provide in all the needs of the whole of the cosmos.

3. The notion of judgement and the image of God as judge: Very specifically in the Book of Revelation and in Isaiah 6:3, sabaōt was interpreted by the LXX in order to indicate the judgement and righteousness of God. An all-powerful God is in control of life because justice must be maintained, and disobedient people should be punished. The combination between judgement and punishment thus helps to establish divine authority and dominionship over all citizens. It sets a moral framework for human behaviour.

As a result of the above-mentioned connections, one can assume and conclude that, because of the political, economic, judicial and cultural background of the pantokratōr-image, God as the Pantokratōr [the idea of God as an imperialistic ruler with autocratic dominionship] had become heavily influenced by cultural and religious contexts, specifically during exilic and post-exilic times and the Jewish diaspora. The Hellenistic and Roman cultural settings, and the later impact of the Byzantine 
image of Christ in iconography, maintained a close association between divine power and pantokratōr dominionship. The very precarious position developed, that, especially in later Christianity, the official church endowed with ecclesial and clerical powers, created a divine ideal in order to legitimise its own claim to worldly and political power.

The following questions arise: in terms of the use of the Bible in theology, is it hermeneutically speaking, justified to maintain a pantokratōr image of God in the light of the previously mentioned theodicy dilemma and people's need for a 'pathetic God' and comfort when they need to face so many afflictions in life? Do 'sadistic fate' or 'compassionate being-with' prevail?

\section{Paradoxical parallelism in the zigzag between sabaōt and miš.pāt}

To trace down the possible meaning of power categories in pastoral caregiving and the need of suffering people for 'strength', to be fortified, and the need for a kind of spiritual 'power' to cope with the demands of life, I would like to turn to the method of paradoxical parallelism.

This method implies that apparent contrasts seeming to oppose one another help one to understand a third level of significance, namely, the intention of a paragraph, chapter or book in the Bible. In the designation of divine authority, this method can help to discover new perspectives on fixed doctrinal, religious and ecclesial paradigms regarding the power of God. Paradoxes work like lightning. The opposing friction of contrasting concepts gives access to new levels or horizons of meaning and hermeneutical options.

Deutoronomy 10:17 emphasises the fact that Yahweh 'shows no partiality and accepts no bribes'. Exodus 23:6-8 states:

Do not deny justice to your poor people in their lawsuits ... Do not accept a bribe, for a bribe blinds those who see and twists the words of the righteous ... Do not oppress an alien.

Deuteronomy 10:18-19 categorically states:

He defends the cause of the fatherless and the widow, and loves the foreigner residing among you, giving them food and clothing. And you are to love those who are foreigners, for you yourselves were foreigners in Egypt.

God's so-called remote transcendence is closely connected to his engaging condescendence. This kind of paradox supports the notion of paradoxical parallelisms that reveal a quite hidden attribute of God, namely, his justice (fairness) coinciding with comfort (paraklessis). The phrase 'God shows no partiality' is quite remarkable. Rendered literally, the Hebrew idiom means, 'the one who does not lift up faces' (Craigie 1976:206) and is borrowed from slave markets in the East.

The metaphor 'God shows no partiality' refers to the trading of slaves. When a merchant comes to buy a slave, he will walk along the line of chained slaves. Their heads would be bowed down. To assess the value of the slave, the merchant will use a stick to hit them under the chin (the lifting of faces)

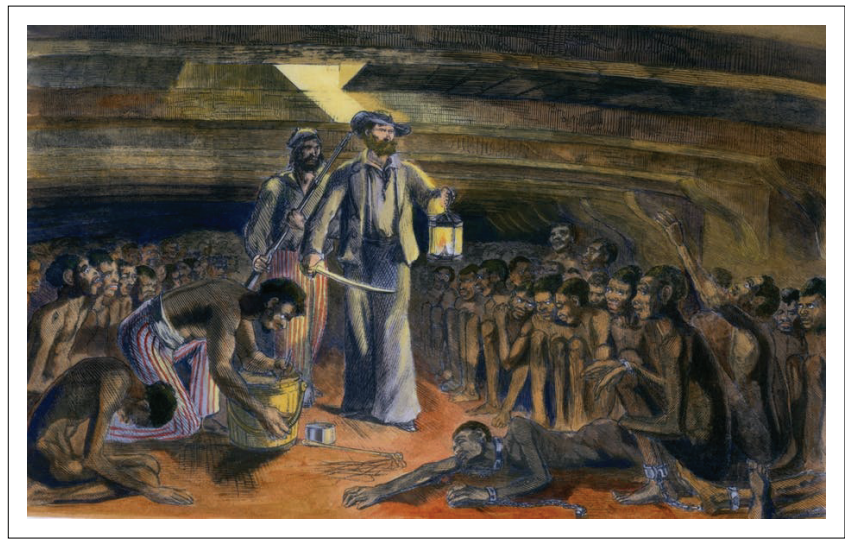

Source: The conversation, n.d., The story of East Africa's role in the transatlantic slave trade, viewed 06 February 2020, from https://www.google.com/search?q=slave+markets+in+the+

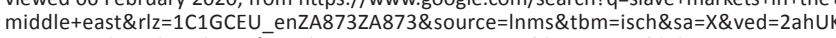
EwiErtnqubznAhVBilwKHfr4BgkQ_AUoAXoECA4QAw\&biw $=1233 \&$ bih $=553 \#$ \#mgrc $=z$ nh3mpaHTFYTM

FIGURE 1: Slave trade, East Africa.

in order to see whether the slave has value or not. Hence, the translation: 'the one who lift up faces'. In the New Testament, this phrase turns up again in Act 10:34-35:

Then Peter began to speak: 'I now realize how true it is that God does not show favoritism but accepts from every nation the one who fears him and does what is right'.

One can say that God displays his 'omnipotence', or 'divine power', or 'sovereignty' or 'splendid majesty' in his otherness; God does not operate like the other gods. God does not assess human beings according to their face value, but according to who they are within the context of our human misery and suffering.

Immediately after Deuteronomy 10:17 follows 10:18: '[h]e defends the cause of the fatherless and the widow'. God's impartiality indicates judgement, justice as well as compassion and love for resident aliens and suffering humans. His power is displayed in the mode (habitus) of compassionate being-with (the passio Dei). This finding corresponds with Von Rad's assertion (cited in Murphy 1990:121-125) that the Deuteronomy texts should be understood in light of the writer's effort to gain a theoretical understanding of the relationship to Yahweh and to prove his trustworthiness. This trustworthiness of God is reflected in his loving care, his overwhelming, overpowering grace which safeguards and comforts his people. Even admonishment and judgement operate within the hẹséd [grace and faithfulness] of Yahweh. His splendid transcendence is displayed in caring condescendence.

\section{God's defencelessness and vulnerable overpowering and/or overwhelming condescendence (weerloze overmacht): A possible re-interpretation?}

The suffering of God is not foreign to the Old Testament (Louw 2016a:306-313). According to Fretheim (1984), God's suffering in the Old Testament is threefold. He suffers because 
of the people's rejection of him as Lord; he suffers with the people who are suffering; he suffers for them because of the fact that in the sacrifices of the Old Testament 'God gives of himself to make forgiveness possible' (Fretheim 1984:139). Texts like Jeremiah 4:14, 13:27, Hosea 6:4 and 11:8 describe God's pathos in his struggle for the future of his covenant people. God is revealed as One who is not vindictive, legalistic or exacting as to matters of judgement. God wants life and not death (Ezk 18:23-24). Although God is deeply wounded by the broken relationship and is revealed as One who does not remain coolly unaffected by the people's rejection, the process of internalisation corresponds with God's permanent and stable faithfulness. 'God's salvific will does not waver; God's steadfast love endures forever' (Fretheim 1984:124). God remains gracious and merciful and abounding in steadfast love.

According to Berkhof (1973), God's defencelessness is the space which he has left for the freedom of human responsibility. Berkhof (1973) does not regard this defencelessness as mere powerlessness, but as a display of God's overwhelming love (power) - weerloze overmacht. God can withdraw because he knows that he will win. This withdrawal is the first visible aspect of a movement which, in fact, is the opposite of withdrawal: it is a new, concealed, active and/or working presence that emerges in Christ's resurrection as victory over sin and death.

Berkhof's (1973) attempt for a possible reinterpretation of the notion of 'God Almighty' is in line with the theological tradition that tries to link the passion of God with the notion of a 'suffering God' (the theopaschitic paradigm). In Het Theopaschitisme, Feitsma (1956) calls this form of theopaschitic interpretation of the power of God (redefining God's Being in terms of suffering) the most ultimate expression in theology of what is meant by God's compassionate being-with. ${ }^{9}$

According to Van de Beek (1984:91-92), behind the motive to maintain the notion of an all-empowering God (omnipotence) is the attempt in doctrine to see God as the Absolute One, the Super King with a driving force (despotes). Behind every event, God functions as the prima causa. Van de Beek (1984) is convinced that more fundamental than the notion of power is the overwhelming phenomenon of God's majestic highness and splendid glory. God's dominion and sovereignty exist in the interest of humankind; the rule of God is to conquer the evil powers of sin and darkness.

It becomes clear that dominionship and sovereignty are closely linked to the notion of the splendid and unique power of God. Fretheim's (1984) conclusion is remarkable in this regard:

9.See in this regard the theopaschitic theology and the connection with the notion of God's weakness and suffering as argued by Bonnhoeffer (1970), Sölle (1973) and Moltmann (1972).

10.Jesus Christ Pantokrator, viewed 05 February 2020, from: https://www.google. $\mathrm{com} / \mathrm{search} ? \mathrm{q}=\mathrm{christ}+$ pantocrator\& $\mathrm{rlz}=1 \mathrm{C} 1 \mathrm{GCEU}$ enZA873ZA873\&source=Inms\& tbm=isch\&sa=X\&ved =2ahUKEwiJ2 qemrvnAhUQrxoKHVOsCnkQ AUoAXoECBIQA $w \& b i w=1233 \& b i h=553 \& d p r=3 \#$ imgrc=1eQ5UHIS-dFtNM\&imgdii=qV_OICWdXS6IM. Public domain, for academic purposes only.

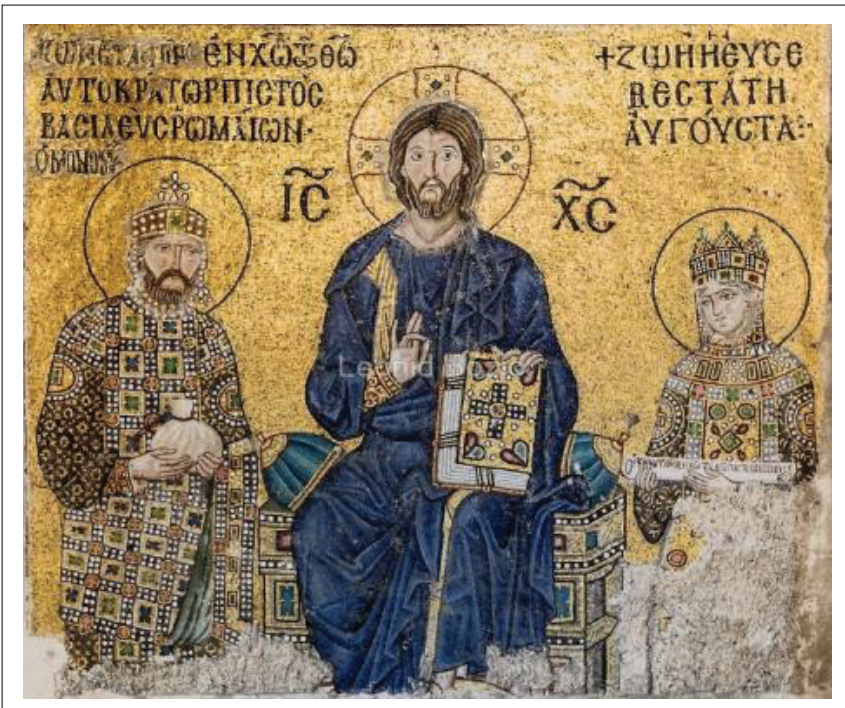

Source: Dreamstime, n.d., Hagia Sophia extraordinary interior Jesus Christ Pantocrator, De. Dome, fresco, viewed 05 February 2020, from https://www.google.com/search?q=christ+pa ntocrator\&rlz=1C1GCEU_enZA873ZA873\&source $=$ nms\&tbm $=$ isch \&sa $=X \& v e d=2$ ahUKE wiJ2_qemrvnAhUQrxoKHV̄OsCnkQ_AUoAXoECBIQAw\&biw=1233\&bih=553\&dpr=3\#imgrc=1 eQ5UHIS-dFtNM\&imgdii=qV OICWd-XS6IM

FIGURE 2: Left: Jesus Christ Pantokratōr. Mosaic Hagia Sophia, Istanbul. Christ is seated in the middle surrounded by royalties representing the imperial positions of dominionship. Here Christ is portrayed as a supreme being (King) with omnipower - dominionship (omnipotence) over the whole of the cosmos. He is dressed in the clothing of a Roman Emperor. ${ }^{10}$

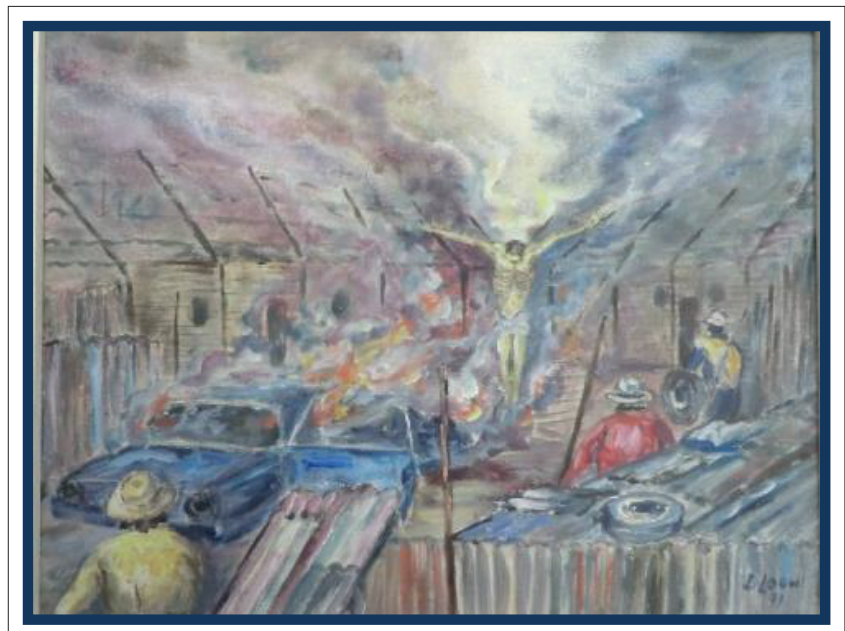

FIGURE 3: Right: In this painting, Crossroads, Cape Flats (Township Crucifixion), the suffering Christ is surrounded by the Roman soldiers. He is depicted as a victim of imperialism and severe oppression. The 'necklaced Christ' (see the car tire right and in hand of oppressors) is portrayed as a victim of the Roman soldiers (apartheid policymakers) within the hell of township life (painting by Louw 1991). The dying Son of God was killed by imperial powers, the injustice of all forms of oppressive imperialism (see Louw 2014:24).

For, even in those instances where the vestments of God's appearance are threaded with lineaments of power, they clothe in vulnerable form. There is no such thing for Israel as a non-incarnate God. (p. 106)

\section{Translating 'El Shadday' into compassionate terminology: The infiniscience (to be) of Yahweh}

The notion of omnipotence became established in many translations of the Bible as the Greek version of the Hebrew phrase 'El Shadday' (Hieronymus used the Latin version deus 
omnipotens). It is a fact that God revealed himself several times in terms of his 'Otherness' - El Shadday. This is the reason for the emphasis in many translations on the fact that God is the Almighty. Genesis 17:1 states: '[ $t$ ]he Lord appeared to him [Abraham] and said, "I am God Almighty"' (see Gn 28:3, 35:11, 43:14, 49:25; Ex 6:3)

From a hermeneutical and exegetical point of view, the etymology of 'El Shadday' is very complex and uncertain. ${ }^{11}$ Van der Toorn (1995:1416) argues that a translation into power categories should be disputed. According to Van der Toorn (1995), shadday is an abbreviation for 'èl šad(d)ay, indicating 'God of the Wilderness'. However, a convincing etymology has until now not been offered so that different scholars present various possible explanations.

It seems that the biblical references to El Shadday or Shadday are, in their present form, exilic or, mostly, post-exilic (Louw 2016a:187; Van der Toorn 1995:1417). One finds that a possible Israelite origin can be connected to different forms of blessings in the Old Testament. For example, in Jacob's blessing of Joseph, Genesis 49:25, El Shadday links the reality or presence of God to parallel of 'the God of your father' - the father being Jacob and the deity presumably Yahweh.

In Ezekiel 10:5, El Shadday refers to a god whose voice is like the moving of a strong wind, comparable to a considerable storm or blowing. This possible connection underlines the fact that El Shadday is many layered with different possible interpretations. In terms of its cultural and historical background, one needs to accept that many contextual and religious factors contributed to its acceptance as an item in Old Testament theology. It is therefore very difficult to draw theological and doctrinal conclusions from a kind of fixed El Shadday tradition in Israel.

I think one can concur with the following conclusion (Van der Toorn 1995):

In the LXX šadday has been rendered with various words and expressions. In the Old Greek version of Job, the rendition (ó)

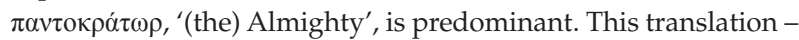
to be interpreted against its contemporary Hellenistic religious and philosophical background - together with its Latin cognate, omnipotens, opened the way for theological speculations concerning omnipotence as a divine attribute. (p. 1421)

From an exegetical viewpoint, eight possibilities exist (see Louw 2000:67-68):

1. Shadday refers to the superior, supreme and strong One who is totally different from all the other deities. The otherness of Yahweh points to God's splendid glory and majesty.

2. Shadday is understood as the insufficient One; Yahweh is therefore incomparable.

3. Yahweh as El is viewed as a positive Being who could be linked to an Arab word for Lord. In this sense, shadday indicates sovereignty (Louw 2016a:187-188).

11.Weipert (1976:875): 'Ein Konsens ist bisher nicht zustandegekommen'.
4. Shadday could be seen in close connection with a Semitic word for breast, the name for a fertile god. In this sense, shadday points to a feminine function of productivity.

5. Shadday could be derived from a verb which means to throw or cast or pour out; it presents movement, not static impassibility.

6. A close link could also exist between Shadday and an Accadian word for mountain - the One who comes from the high place, or from the mountain. This explains the connection to splendid glory and unique majesty.

7. A link could exist with a Sumerian word for God, meaning 'the one who knows your heart'. Shadday then indicates thorough knowledge, connection and passion.

8. Several scholars suggest a Ugaritic connection with Astarte: somebody from the veld or the floor - belonging to the desert or wilderness.

The only conclusion to be derived from the above exposition is that the phrase 'El Shadday' should be designated within the context of the various texts and could never be captured by a substantial or personified or psychic or abstract, metaphysical hermeneutics. It should be borne in mind that the concept is many layered, with different associations in different biblical accounts regarding the intervention of a divine factor in the lives of the people of Jahwe . 'El Shadday' represents the uniqueness (sovereignty) and greatness of Yahweh who reveals himself not in abstract metaphysical terminology but by means of the tribal and familial metaphor, as a Father ${ }^{12}$ and the living God of the covenant. Therefore, it remains a crucial question whether Hieronymus' translation (omnipotens) and the pantokratōr image which so deeply influenced the Western thought was correct. This explains the attempt to find other categories to translate the notion of divine power.

This critical warning is in line with the finding of Bachmann (2002:196), namely, that the use of almighty speech (pantokratōr terminology) does not refer to the force and strength of 'I-can-do-everything-and-all' (Alleskönner), but the sovereignty of God as a source for a vivid and meaningful hope. Pantokratōr should be understood as an

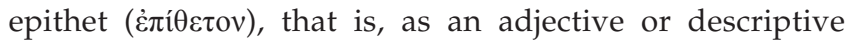
phrase used to indicate a specific characteristic of God, a by-name as displayed in activities that became repetitive and became a common usage. According to Bachmann (2002:197-198), the epithet of almightiness (omnipotence, pantokrator) gave birth to fictitious and speculative associations and expectations. It should be avoided in divine designation, ${ }^{13}$ because God's power points to a kind of hope that is in fact opposite to all factuality, and, thus, an indication of an 'eschatological conqueror' (eschatologischer Sieger). For Bachmann (2002:201), it is important to

12.Weipert (1976:882): "Es ist somit warscheinlich, dass einer der "Vatergötter" tatsächlich der (,el) gewesen ist, und P hier, wie öfter, altes Gut benutzt und generalisiert hat'.

13.Bachmann's (2002:198) suggestion: '... die Redeweise van Gottt als dem Onipotenten, bzw. Als dem Allmächtigen im Christentum weitestgehend zu meiden - zumindest dort, wo es gerade auch um die Aufnahme eben des frühchrirtlichen Terminus pantokrator (bzw. Omnipotens) geht-'. 
acknowledge the fact that Christ is not Constantine the Great, so that divine designation within the speech of the Christian faith should be linked to the suffering (God is not contra suffering) of humankind. One has to reckon with the fact that the One on the throne is the Slaughtered Lamb (Bachmann 2002:200).

We conclude that omnipotence should not be interpreted against the background of the Hellenistic pantokratōr image (strength and violent power), nor in terms of the Roman Caesar (despotes). El Shadday rather describes God's unique revelation (his sovereign majesty and splendid glory); it portrays Yahweh as displaying overwhelming love and steadfast faithfulness. Omnipotence describes a power which is closely connected to God's covenantal encounter and graceful identification with our human misery. 'Omnipotence' also corresponds with righteousness and social justice. It is displayed in a very splendid way by God's compassionate being-with his people. God as 'El Shadday' refers to a unique display of God's caring interventions so that it is impossible to compare 'his power' to any other forms of power displayed by other deities within the ancient, Hebrew context.

\section{Omni-potence: The life-giving spirit}

Within the New Testament, the connection between divine empowerment, the overwhelming display of God's 'overpowerment' (supervincimus) - victory over death - because of the resurrection of Christ, has huge implications. As a result of the resurrection of Christ, pastoral empowerment is about the 'incomparably great power' within believers: '[ $t]$ hat power is like the working of his mighty strength, which he exerted in Christ when he raised him from the dead' (Eph 1:19-21); believers are equipped with a dominionship over all brutal and evil forces. 'Almightiness' now attains the meaning of a 'life-giving spirit'. Paul reasons in 1 Corinthians 15:44: ' $[t]$ he first man Adam became a living being, the last Adam, a life-giving spirit'.

The notion of a life-giving spirit is quite remarkable when it is connected to the ministerial abilities of parrhesia - the boldness of being and speech that renders believers to oppose destructive resistance. Within an African context, the notion of a life-giving spirit is most powerful. As Maboea (2002:133) aptly pointed out, the influence of life-giving power and its role in human relationships and communities is a vital ingredient of believers within an African context. It is also an ingredient of fellowship (koinonia) and during services, members are enabled by this life-giving spirit to cope with the threat of evil forces and the difficulties of life (Maboea 2002):

The holistic ministry and experience of the influence of God's power in their church services (African Initiated Churches AIC) give the community life. It is in these church services that their basic needs are effectively met. Life-giving power in the name of Jesus provides complete deliverance. (p. 133)

Omni-potence gains in this context the meaning of a kind of divine designation that promotes a holistic approach to life.
The point is: empowerment explicates the fact that the 'Living God' is always there where we are - divine inhabitation through and by the Holy Spirit even within human bodies. In this sense, a divine life-giving power directs daily living in terms of a continuing divine presencing - the experiential verbing of God's empowerment.

With reference to the topic of the article, the use of the Bible in theology, theological designation is complex, full of hermeneutical risks. One needs to probe into the historical, geographic, cultural, political, economic and religious background of texts and narratives. The stories of the Bible are zigzag and do not follow the rational logic of cause and effect. That is the same with the attempt to designate the otherness of God (the naming of God's splendid glory and grace) in terms of verbing categories, that is, the designation of divine faithfulness - the consistency of being-there and being-with.

\section{The infiniscience of Yahweh: The deconstruction of omni-power and the paradigm switch to 'ta splanchna-power'}

The El Shadday of Yahweh is based on the respect in Jewish hermeneutics to render God not as a personified substance, but as an 'operating verb'. The noun Jahve, is derived from the verb hjh (Hebrew), which means 'to be' (see also MillerMcLemore 2012:8). The covenantal presence of God attains the mode of an infinitive, namely an on-going divine endeavour; the promise to be there where human beings are. Infiniscience indicates an active interpenetration of God in cosmos and human life. This 'in' of God is, in essence, an osmatic and pneumatic in.

The pneumatic 'in' of God should be interpreted in verbal categories and the infinitive tense. In this regard, the use of 'gerunds' should be considered (Louw 2011, 2016b:336-353). In English:

[G]erunds are words that end with -ing and look like verbs but function as nouns. That is, they are nouns (words that name persons, places, ideas, etc.) that contain action; they are verbs used as nouns. (Louw 2016b:347; Miller-McLemore 2012:8)

Scholars in Old Testament Studies assert that the Jewish and Christian God is more verb than noun-like:

Several biblical scholars translate God's answer to Moses' request for God's name in Exodus 3;14, YHWH, as 'I am who I am becoming' rather than the etymology of YHWH, I am who I am. (Miller-McLemore 2012:8)

The point is, in either case, YHWH is a 'verbal form' and indicates the sustainable presence of an ongoing intervention and promise of God's faithful and covenantal being-with.

The name Jahve, thus, does not describe a fixed theological principle or definition of a substance or static noun; it rather points to what one can call infinisciences of divine engagements 
(ongoing modes of compassionate divine interventions). This divine mode of compassionate infiniscience (as a display of spiritual power) is illustrated in a very poignant way by what in the New Testament is called ta splanchna - the pity and mercy of God (Louw 2011).

\section{The bowel categories of compassionate empowerment}

The value of theopaschitic thinking for the praxis of God is that it proposes a shift from the substantial approach to the relational and encounter-paradigm (Berkhof 1973:32-33). The switch is then from the attempt of orthodoxy to uphold ecclesial triumphantilism (Hall 1993:100-101), a theology of glory (theologia gloriae) and an imperialistic ecclesiology of omnipotence (powerful force), ${ }^{14}$ to a theologia crucis $^{15}$ of weakness, suffering and passion.

It is my contention that the passio Dei displays a praxis of $t a$ splanchna. The latter is related to the Hebrew root rhm, to have compassion. It is used in close connection to the root hnn, which means to be gracious. Together with oiktirmos and heesed, it expresses the being quality of God as connected to human vulnerability and suffering (Esser 1978:598). The verb splanchnizomai (Louw 2016a:313, 2016b:348) is used to make the unbounded mercy of God visible and experiential.

In general Greek, to splanchnon refers to bowel categories including the most sensitive and vulnerable parts, the heart, lung, liver, and also the spleen and the kidneys. During the sacrifice, they are removed for the sacrificial meal. With reference to humans, splanchna refers to the human entrails, especially for the male sexual organs and the womb, as the site of the powers of conception and birth. Ta splanchna expresses pity, compassion, sympathy, love and could be rendered as the theological explanation of the passio Dei within the praxis of human misery (Louw 2011, 2016a:313-318). 'The oldest form of the verb is splanchneuō, eat the entrails, prophesy from the entrails' (Esser 1978:599; Louw 2016b:348). ${ }^{16}$

Splanchnizomai reveals the very character of God's 'omnipotency'. The ability (potency, power) of God is, in New Testament terminology, about a theology of the entrails reflecting and exemplifying the mode of God's being-there and being-with. Noteworthy in this regard is the fact that

14.See in this regard the remark of Hall (1993): "[p] owerful people demand powerful deities - and get them!'; 'Power - and precisely power understood in the usual sense - is of the essence of divinity shaped by empire' (Hall 1993:107, 108).

15.'Greek epistemology could not take account of the surprise needed to recognize God on the cross ... It did not envision suffering as a source of knowledge' (Jon Sobrino cited in Hall 1993: note 8, p. 105).

16.It is interesting to note the cases where Christ responded to human suffering with the contraction of the entrails, expressing messianic compassion. For example, the leper with his petition (Mk 1:41), the people like sheep without a shepherd (Mk 6:34); the sight of the harassed and exhausted crowd (Mt 9:36); two blind men who besought him (Mt 20:34); the widow at Nain mourning her only son (Lk 7:13). In Luke 15:11-32, the prodigal son, splanchnizomai expresses the strongest feeling of a merciful and loving reaction (verse 20). In the parable of the Good Samaritan (Lk 10:33), splanchnizomai expresses the attitude of complete willingness to use all (Lk 10:33), splanchnizomai expresses the attitude of complete willingness to use all
means, time, strength and life, for saving at the crucial moment (Esser 1978:600; Louw 2016b:336-353). within these texts, ta splanchna represents a large range of different forms of human weakness and vulnerability. It is connected to illness and health; dying and mourning; loss and grief; violence and injustice; burnout; and hunger, estrangement and remorse.

\section{Conclusion}

To my mind, the method of paradoxical parallelism as applied to the texts in Deuteronomy 10:17-19 was most helpful to discover how sabaoth should be read in close connection with the justice of God as displayed in his caring concern for the fatherless, widowers, poor and strangers. The apparent paradox helped to understand the complexity of translating God's power as well as the richness and many-layered dimensions attached to the designation of divine power.

From a praxis point of view, the question regarding God's power is not whether God is behind these events (causative approach) but what is God's attitude and intention within these events? What is the mode of God's being within our human predicament?

The notion of the passio Dei totally reframes our understanding of who God is (mode of God) and what is meant by God's power (Louw 2016b:336-353). The latter, now understood as passion and compassion (overwhelming power defencelessness and weakness) and not as omnipotent force in the mode of a Caesar-like power, reveals ta splanchna empowerment and not pantokratōr imperialism.

The application of the passio Dei paradigm in the hermeneutics of divine power is not meant to ease out the tension and paradoxical discrepancy between God's sovereignty (power) and his solidarity (pathos). An overemphasis of God's identification with suffering presents the danger that God's immanent experience is traded for his sovereignty. On the other hand, a theology that emphasises God's sovereignty and his punishment, thereby distancing God from suffering, incurs the danger of presenting God as alienated from reality (the absence of God). This antinomy brings us to the heart of the theodicy question.

According to theopaschitism, God does not will evil as such, but he himself even suffers in some way with, or under, evil in order to display his compassion (pathos). The cross of Christ becomes the proof that God is not unyielding and sadistic but deeply affected by our human misery. God identifies with suffering and is not apathetic towards it. In his sym-pathetic involvement with suffering, God shows his compassion, thereby proclaiming that suffering is directly opposed to his will. It is in this regard that a theopaschitic hermeneutics should promote the concept of a dynamic 'verbing God' - the infinitive of God's presencing within human misery displaying his faithfulness, justice and fulfilment of divine promises. 
It is my contention that the passio Dei displays a praxis of ta splanchna (Louw 2011). The latter is related to the Hebrew root rhm, to have compassion. Together with rhm, oiktirmos and $h \bar{e} s \bar{e} d$, divine power expresses the being quality of God in verbing terminology. Thus, the otherness of El Shadday: the loving of foreigners. The name Jahve, thus, does not describe a fixed theological principle or metaphysical definition of an immutable substance or static noun (impassibilitas Dei); it rather points to what one can call the infinisciences of divine engagements: the verbing of God as displayed in the passio Dei.

The so-called atheist Ludwich Feuerbach was right when he emphatically made the following statement: a God without a heart (compassion) is an idol; God as pure passion, the God of pure suffering (die Passion pura, das reine Leiden) (Feuerbach 1904:127).

\section{Acknowledgements Competing interests}

The author declares that he has no financial or personal relationships which may have inappropriately influenced him in writing this article.

\section{Authors' contributions}

I declare that I am the sole author of this research article.

\section{Ethical consideration}

This article followed all ethical standards for a research without direct contact with human or animal subjects.

\section{Funding information}

This research received no specific grant from any funding agency in the public, commercial or not-for-profit sectors.

\section{Data availability statement}

Data sharing is not applicable to this article as no new data were created or analysed in this study.

\section{Disclaimer}

The views and opinions expressed in this article are those of the author and do not necessarily reflect the official policy or position of any affiliated agency of the author.

\section{References}

Bachmann, M., 2002, Göttliche Allmacht und theologische Vorsicht. Zu Rezeption, Funktion und Konnotationnen des biblisch-frühchristlichen Gottesepithetons pantokrator, Stuttgarter Bibelstudien, 188, Verlag Katholisches Bibelwerk GmbH pantokrator

Berkhof, H., 1973, Christelijk geloof, Callenbach, Nijkerk.

Berkhof, H., 1983, Christian faith, Eerdmans, Grand Rapids, MI.

Bonhoeffer, D., 1970, Widerstand und Ergebung: Briefe und Aufzeichnungen aus der Haft, Kaiser, München.

Boulton, J.P.A., 2007, 'The complex face of God', in K.A. Richardson \& P. Cilliers (eds.), Explorations in complexity thinking: Pre-proceedings of the 3rd International Workshop on Complexity and Philosophy, pp. 262-278, ISCE Publishing, Mansfield.
Braumann, G., 1975, 'Паракав́w', in C. Brown (ed.), The new international dictionary of New Testament theology, vol. I, pp. 569-571, The Paternoster Press, Exeter.

Craigie, P.C. 1976, The Book of Deuteronomy, Eerdmans, Grand Rapids.

Colley, C., 2004, The omnipotence of God, Apologetic Press, Montgomery, AL.

Davies, O., 2001, A theology of compassion. Metaphysics of difference and the renewa of tradition, William B. Eerdmans Publishing Company, Grand Rapids, MI.

Dreamstime, n.d., Hagia Sophia extraordinary interior Jesus Christ Pantocrator, De. Dome, fresco, viewed 05 February 2020, from https://www.google.com/search?q $=$ christ+pantocrator\&rlz=1C1GCEU_enZA873ZA873\&source=Inms\&tbm=isch\&sa
$=$ =X\&ved=2ahUKEwiJ2_qemrvnAhUQ̈rxoKHVOsCnkQ_AUoAXoECBIQAw\&biw $=123$ $3 \&$ bih=553\&dpr=3\#imgrc=1eQ5UHIS-dFtNM\&imgdii=qV_OICWd-XS6IM

Ellens, J.H., 1987, Psychotheology: Key issues, University of South Africa, Pretoria

Esser, H.-H., 1978, 'Splanchna', in C. Brown (ed.), Dictionary of New Testament theology, vol. 2, pp. 599-601, Paternoster Press, Exeter.

Feitsma, M., 1956, Het theopaschitisme: Een dogma-historische studie over de ontwikkeling van het theopaschitisch denken, Kok, Kampen.

Feldmeier, F., 1995, 'Almighty ravtoкрат $\rho^{\prime}$ ', in K. Van der Toorn, B. Becking \& P.W. Van der Horst (eds.), Dictionaries of Deities and Demons in the Bible (DDD), pp. 35-41, E.J. Brill, Leiden.

Feuerbach, L., 1904, Das Wesen des Christentums, Verlag Philipp Reclam, Leipzig.

Fretheim, T.E., 1984, The suffering of God, Fortress, Philadelphia, PA.

Hall, D.J., 1993, Professing the faith. Christian theology in a North American context, Fortress Press, Minneapolis, MN.

Hoffman, J. \& Rosenkrantz, G., 2017, 'Omnipotence', in Stanford Encyclopedia for philosophy, pp. 58-84, Stanford University, Stanford, CA, viewed 29 January 2020, from https://plato.stanford.edu/entries/omnipotence/.

Keller, J.A., 2007, Problems of evil and the power of God, Ashgate, Hampshire.

Kempen, M., 2015, 'Coaching als abduktiver Prozess vor dem bleibenden Geheimnis. Die Theorie U aus pastoralpsychologischer Perspektive', Doctoral dissertation, Philosophisch - Theologische Hochschule, Sankt Georgen, Institut fur Pastoralpsychologie und Spiritualität, Frankfurt am Main.

Louw, D.J., 2000, Meaning in suffering. A theological reflection on the cross and the resurrection for pastoral care and counselling, Peter Lang, Frankfurt am Main.

Louw, D.J., 2011, 'Ta splanchna: A theopaschitic approach to a hermeneutics of God's praxis. From zombie categories to passion categories in theory formation for practical theology of the intestines' HTS Teologiese Studies/Theological Studies 67(3), Art.\#1087, 13 pages. https://doi.org/10.4102/hts.v67i3.1087

Louw, D.J., 2014, Icons. Imaging the unseen. On beauty and healing of life, body and soul, Sun Press, Stellenbosch.

Louw, D.J., 2016a, Wholeness in hope care. On nurturing the beauty of the human soul in spiritual healing, Lit Verlag, Wien.

Louw, D.J., 2016b, 'Missio Dei as embodiment of Passio Dei. The role of God-images in the mission-outreach and pastoral caregiving of the church. A hermeneutical approach', Missionalia 44(3), 336-354.

Louw, D.J., 2020, 'Die estetika van 'n skreeu-lelike, "weerlose God." Skilderkuns as medium in prosesse van teologiesparadigmatiese transformasie - ver-beeld-ende stank (skúbalon) vir skandalige on-dank (skandalon)', LitNet Akademies 17(1), 298-320.

Maboea, S.I., 2002, The influence of life-giving power in the African traditional religion and the Zionist Churches, CB Powell Bible Centre, University of UNISA, Pretoria.

Mathews, T.F., 1993, The clash of Gods. A reinterpretation of Early Christian Art, Princeton University Press, Princeton, NJ.

Miller-McLemore, B.J., 2012, 'Introduction. The contributions of practical theology', in B.J. Miller-McLemore (ed.), The Wiley-Blackwell companion to practical theology, pp. 1-20, Malden/Oxford/Chisester.

Moltmann, J., 1972, Der gekreuzigte Gott, Kaiser, München.

Murphy, R.E., 1990, The tree of life: An exploration of Biblical Wisdom Literature, Doubleday, New York, NY

Nouwen, J.M., 1994, The wounded healer: Ministry in contemporary society, Image, New York, NY.

Parker, D.C., 2009, Manuscripts, texts, theology. Collected papers, 1977-2007, De Gruyter, Berlin.

Robinson, M., 2017, The faith of Donald Trump: A Christian President?, p. 1, Kindle edn., viewed 11 January 2020, from https://www.amazon.com/Faith-DonaldTrump-Christian-President-ebook/dp/B01MS7GA1J.

Rodríguez, J.C.H., 2019, 'Responses to the paradoxes on the omnipotence of God', Pensamiento. Revista de Investigación e Información Filosófica 75(283 S. Esp), 469-548.

Sölle, D., 1973, Leiden, Kreuz, Stuttgart.

Strümpfer, J.W., 2006, 'The strengths perspective: Fortigenesis in adult life', Journal for Social Indicators Research 77(1), 11-36.

Suurmond, P.B., 1981, God is machtig-Maar hoe?, Ten Have, Baarn.

The conversation, n.d., The story of East Africa's role in the transatlantic slave trade, viewed 06 February 2020, from https://www.google.com/search?q= slave+markets+in+the+middle+east\&rl $z=1$ C1GCEU enZA873ZA873\&source $=$ Inm s\&tbm=isch\&sa=X\&ved=2ahUKEwiErtnqubznAhVBilwKHfr4BgkQ AUoAXoECA4Q Aw\&biw $=1233 \&$ bih $=553 \#$ imgrc $=z \quad$ nh3mpaHTFYTM

Tillich, P., 1965, The courage to be, London, Collins.

Van de Beek, A., 1984, Waarom? Over lijden, schuld en God, Callenbach, Nijkerk. 
Van den Brink, G., 1993, Almighty God. A study of the Doctrine of divine omnipotence, Kok Pharos Publishing House, Kampen.

Van der Horst, P.W., 1995, 'God (II) Өcós', in K. Van der Toorn, B. Becking \& P.W. Van der Horst (eds.), Dictionaries of Deities and Demons in the Bible (DDD), pp. 692-699, E.J. Brill, Leiden.

Van der Toorn, K., 1995, 'God (I) יהים,' in K. Van der Toorn, B. Becking \& P.W. Van der Horst (eds.), Dictionaries of Deities and Demons in the Bible (DDD), pp. 668-692, E.J. Brill, Leiden.
Van Wyk, I., 2019, 'Zuma's religious leanings could explain his lack of shame', News Opinion, 15 July, p. 1, viewed 27 January 2020, from https://www.iol.co.za/news/ opinion/zumas-religious-leanings-could-explain-his-lack-of-shame-29238732.

Weipert, M., 1976, 'Addonaj (Gottesname)', in E. Jenni \& C. Westermann (eds.) Theologisches Handwörterbuch zum Alten Testament, Band II, Kaiser, München.

West, G., 2010, 'Jesus, Jacob Zuma, and the New Jerusalem: Religion in the Public Realm between Polokwane and the Presidency', Journal for the Study of Religion 23(1/2), 43-70. https://doi.org/10.4314/jsr.v23i1-2.69793 